\title{
Determination of the Volatile Compounds of Chimonanthus praecox (Wintersweet) Used as an Ornamental Plant in the Parks of Burdur (Gölhisar)
}

\author{
Sevgin Özderin *, Ebru Hatice Tığglı Kaytanlığlu ${ }^{2}$, Hüseyin Fakir ${ }^{3}$ \\ 1* Muğla Sitkı Koçman University, Köyceğiz Vocational High School, Departmant of Forestry, Muğla, Turkey, (ORCID: 0000-0002-4511-5229), \\ sevginozderin@mu.edu.tr \\ ${ }^{2}$ Isparta Applied Sciences of University, Faculty of Forest, Departmant of Forest Engineering, Isparta, Turkey, (ORCID: 0000-0002-9165-6675), \\ ebrukaytanlioglu@isparta.edu.tr \\ ${ }^{3}$ Isparta Applied Sciences of University, Faculty of Forest, Departmant of Forest Engineering, Isparta, Turkey, (ORCID: 0000-0002-6606-8011), \\ huseyinfakir@isparta.edu.tr
}

(First received 6 October 2021 and in final form 6 December 2021)

(DOI: 10.31590/ejosat.1005547)

ATIF/REFERENCE: Özderin, S., Kaytanlığlu, E. H. T., Fakir, H., (2021). Determination of the Volatile Compounds of Chimonanthus praecox (Wintersweet) Used as an Ornamental Plant in the Parks of Burdur (Gölhisar). European Journal of Science and Technology, (31), 916-920.

\begin{abstract}
In this study, it was aimed to determine the volatile compounds of the flowers of wintersweet (Chimonanthus praecox) belonging to the Calycanthaceae family which is an exotic species and used as an ornamental plant in the parks of Burdur (Gölhisar) in Turkey. Flower specimens were dried at room temperature, followed by determining their volatile compounds by HS-SPME/GC-MS analysis. As a result of the analysis, 33 volatile compounds belonging to the Chimonanthus praecox species were determined, and the first three main compounds were $\beta$-Ocimene at a rate of $61.87 \%$, Sabinene at $7.65 \%$ and Caryophyllene at $5.03 \%$. The findings that were obtained were compared to those obtained in other studies.
\end{abstract}

Keywords: Chimonanthus praecox, exotic species, volatile compound, $\beta$-ocimene, Turkey.

\section{Burdur (Gölhisar) Parklarında Süs Bitkisi Olarak Kullanılan Chimonanthus praecox (Kış Tatlı Çalısı)'un Uçucu Bileşenlerinin Belirlenmesi}

Öz

Bu çalışmada egzotik bir tür olan ve Burdur (Gölhisar) parklarında süs bitkisi olarak kullanılan Calycanthaceae familyasına ait kış tatlı çalısı (Chimonanthus praecox)'nın çiçek uçucu bileşenlerinin belirlenmesi amaçlanmıştır. Çiçek örnekleri oda sıcaklığında kurutulmuş ve daha sonra HS-SPME/GC-MS analizi ile uçucu bileşenleri belirlenmiştir. Analiz sonucunda Chimonanthus praecox türüne ait toplam 33 uçucu bileşen belirlenmiş ve ilk üç bileşen olarak; $\beta$-Osimen \%61,87, Sabinen \% 7,65, Karyofilen \%5.03 tespit edilmiştir. Elde edilen bulgular yapılan diğer çalışmalarla karşılaştırılmıştır.

Anahtar Kelimeler: Chimonanthus praecox, egzotik tür, uçucu bileşen, $\beta$-osimen, Türkiye.

\footnotetext{
* Corresponding Author: sevginozderin@mu.edu.tr
} 


\section{Introduction}

Turkey has a broad variety of plants due to its geographical structure, climatic conditions, its location in the intersection of three different floristic regions, geological characteristics, varying altitudes in the range of $0-3000 \mathrm{~m}$ and its inclusion of terrestrial and aquatic ecosystems. It was reported that there are about 12000 taxa in Turkey of which more than a third are endemic (Güner, 2012). The fact that Turkey has favorable conditions for growing medicinal and aromatic plants increases the importance of these plants. Medicinal and aromatic plants, whose areas of use and consumption quantities are increasing day by day worldwide, also have increasing economic significance. Many medicinal and aromatic plants are used in various fields due to their different effect mechanisms with their seeds, flowers, fruits, leaves or roots (Maksimoviç et al., 2005). While plants that are rich in volatile oils among medicinal and aromatic plants are increasingly gaining significance, the demand for these resources has increased much in recent years and is still increasing. These plants are frequently utilized especially in the perfume and cosmetics industries for their pleasant scent and varying contents (Genç, 2010). Essential oils are oil-like mixtures that are produced from plant parts such as roots, stems, leaves, fruits, peels and flowers or plant-derived resources that are in a liquid state or sometimes frozen at room temperature, can easily be crystallized, are generally colorless or light yellow and have a strong scent (Kevseroğlu,1993). As essential oils have a broad area of usage, their chemical structures have been investigated, and their biological activities have been a topic of curiosity (Yayl, 2013). While the effects of essential oils vary depending on their active ingredients, many essential oils have antimicrobial, carminative, choleretic, sedative, diuretic and antispasmodic effects (Maksimoviç et al., 2005).

Today, plants with such value are included in planting work in landscape design areas, and they raise much interest. In addition to naturally available species growing in Turkey, several exotic species may also be used in rural and urban areas in the country for aesthetical, functional, economic and psychological purposes. A significant portion of the species that are used is imported. A part of these species is produced in nurseries in the country. Foreign-origin (exotic) plants that are used in Turkey may be grouped under trees and shrubs, bushes, and herbaceous perennial and annual plants (Sögüt, 2018). One of the plants that are used as exotic ornamental plants in parks and gardens in Turkey is Chimonanthus praecox (L.). C. praecox is a deciduous bush endemic to China and belonging to the genus Chimonanthus in the Calycanthaceae family, which is known as 'làmei' or 'La Mei Hua' in Chinese, 'reubai' in Japanese and Korean and 'wintersweet' in English (Sahito et al., 2019). Due to the pleasant aromatic scent of essential oils obtained from the flowers of $C$. praecox, which flowers from December to February, the plant is utilized as one of the most expensive components of perfumes and flavors (Li et al., 2009). With its medicinal importance and flowers with a highly pleasant scent, C. praecox, which has naturally grown in China for more than 1000 years, is prevalently grown in parks and gardens, pots and in the form of cut flowers as an ornamental plant in temperate zones (Sahito et al., 2019). In China, the flowers and buds of C. praecox have been traditionally used in the treatment of tightness in the chest, heat stroke, burns, bruises, and especially coughs and rheumatic diseases (Ueyama et al., 1990; Lv et al., 2012; Morikawa et al., 2014; Xu et al., 2000). Modern pharmacological studies have reported C. praecox extracts' antifungal (Yu-et al., 2013), antiviral and immunoregulatory (Wang et al., 2011; Shu et al., 2019; Zhang et al., 2009; Kitajima et al., 2006) activities. Previous studies on the chemical contents of $C$. praecox have revealed that its flowers are rich in essential oils (Gao et al., 2011), its flowers, fruits and leaves contain many sesquiterpenoids (Wang, 2011), glycosides (Wang et al., 2011) and alkaloids, while its rhizomes and seeds have antifungal effects and are rich in alkaloids and flavonoids (Ma et al., 2010; Wang et al., 2012; Zhang et al., 2009; Kitajima et al., 2006; Takayama et al., 2004).

Essential oils are a complex mixture of secondary metabolites obtained from aromatic and medicinal plants that have been in great demand in perfumery, food, veterinary, household products, cosmetic and pharmaceutical industries due to their wide range of pharmacological properties (Siddique et al., 2015; Alves-Silva et al., 2020). Turkey is producing country traditionally a medical and aromatic plant and essential oil. The sector of aromatic and medicinal plants and their essential oils is very promising at the socio-economic level for developing countries and Turkey can become a player in this market (Giray, 2019). The composition of the essential oil is depends on plant type, geographical location and collection season (Maria et al., 2008). Wintersweet $(C$. praecox), an important ornamental plant, has unique fragrant aroma and winter-flowering properties, which are used as a source of cosmetics industries. In this study it was aimed to determine the volatile compounds of $C$. praecox (wintersweet), which has specific botanical properties and is an exotic plant that is grown as an ornamental plant in Burdur-Bucak in Turkey (Figure 1). The volatile compounds of $C$. praecox were determined using the solid phase microextraction (SPME, Supelco, Germany) method.

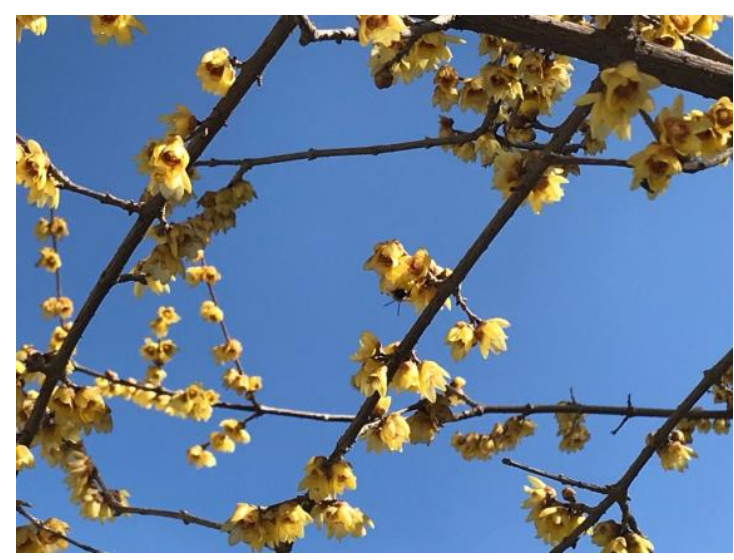

Figure 1.C. praecox flowers

\section{Material and Method}

\subsection{Material}

Fresh C. praecox flower samples, which constituted the material of this study, were collected from parks located in the center of the province of Burdur (Gölhisar) in Turkey in their flowering period (January-February 2020). The collected samples were put in bags, the bags were coded and labeled, and their labels included information on the time of collection, location and altitude. After collection, these specimens were dried in a semishaded, airy place at room temperature to be used in essential oil analyses later. Following the drying process, the specimens were brought to the Forest Botany Department Laboratory of the Faculty of Forestry at Isparta University of Applied Sciences for conducting essential oil analyses. The identification of the plant 
specimens was made at the Biology Department Herbarium of the Faculty of Science and Letters at Süleyman Demirel University. The identified plant specimens were preserved at the Faculty of Forestry Herbarium at Isparta University of Applied Sciences.

\subsection{Determination of floral volatile compounds by HS- SPME/GC-MS analysis}

In our study, flower specimens of $C$. praecox were collected by visiting parks and gardens where this plant was grown as an ornamental plant in central Burdur (Gölhisar) in its vegetation period. The collected flower specimens were put in bags and transported to the Laboratory of the Faculty of Forestry at Isparta University of Applied Sciences within the same day without waiting and without any exposure to sunlight. The collected plant material was dried until it reached a constant weight at room temperature $\left(25^{\circ} \mathrm{C}\right)$.

The floral aromatic components of the $C$. praecox flowers were determined with the gas chromatography - mass spectrometry (GC-MS) method combined with the headspace solid phase microextraction (HS-SPME) method. Taking the method of solid phase microextraction (SPME, Supelco, Germany) as a basis, after keeping 2-g flower specimens put into a $10-\mathrm{mL}$ vial at $60^{\circ} \mathrm{C}$ for $30 \mathrm{~min}$, volatile compounds were absorbed from the headspace using 75- $\mu \mathrm{m}$-thick CarboxenPolydimethylsiloxane (CAR/PDMS)-coated fused silica fiber and immediately injected into the capillary column (Restek Rx-5 Sil MS $30 \mathrm{~m} \times 0.25 \mathrm{~mm}, 0.25 \mu \mathrm{m}$ ) or an HS-SPME-compatible GCMS device (Shimadzu 2010 PLUS). After the oven temperature was kept at $40^{\circ} \mathrm{C}$ for $2 \mathrm{~min}$, it was programmed to increase up to $250^{\circ} \mathrm{C}$ at a heating rate of $4^{\circ} \mathrm{C}$ per min. The injector and detector temperatures were set at $250^{\circ} \mathrm{C}$. The ionization mode was selected as EI $(70 \mathrm{eV})$, while the carrier gas was helium $(1.61 \mathrm{~mL} / \mathrm{min})$. The Wiley, NIST, Tutor and FFNSC libraries were utilized in the identification of the volatile compounds of the essential oil.

\section{Results and Discussion}

In this study, 33 volatile compounds were determined in the essential oil of the $C$. praecox flower specimens, and these compounds are listed in Table 1. Among these compounds, the main compounds were determined as $\beta$-Ocimene $(61.87 \%)$, Sabinene $(7.65 \%)$ and Caryophyllene $(5.03 \%)$.

Table 1. Floral volatile compounds of wintersweet (Chimonanthus praecox)

\begin{tabular}{|l|l|l|l|l|}
\hline R.T & Components & Flowering & Formula & Category \\
& & & & \\
\hline 8.628 & $\alpha$-Thujene & 0.41 & $\mathrm{C}_{10} \mathrm{H}_{16}$ & $\mathrm{MH}$ \\
\hline 8.870 & $\alpha$-Pinene & 0.24 & $\mathrm{C}_{10} \mathrm{H}_{16}$ & $\mathrm{MH}$ \\
\hline 10.349 & Sabinene & $\mathbf{7 . 6 5}$ & $\mathrm{C}_{10} \mathrm{H}_{18} \mathrm{O}$ & $\mathrm{OM}$ \\
\hline 11.037 & $\beta$-Myrcene & 0.83 & $\mathrm{C}_{10} \mathrm{H}_{16}$ & $\mathrm{SH}$ \\
\hline 11.623 & 1-Phellandrene & 1.14 & $\mathrm{C}_{10} \mathrm{H}_{16}$ & $\mathrm{MH}$ \\
\hline 12.335 & Benzene, methyl & 0.93 & $\mathrm{C}_{10} \mathrm{H}_{14}$ & $\mathrm{AH}$ \\
\hline 12.524 & dl-Limonene & 2.82 & $\mathrm{C}_{10} \mathrm{H}_{16}$ & $\mathrm{MH}$ \\
\hline 12.844 & cis-Ocimene & 0.94 & $\mathrm{C}_{10} \mathrm{H}_{16}$ & $\mathrm{MH}$ \\
\hline 13.288 & $\boldsymbol{\beta}$-Ocimene & $\mathbf{6 1 . 8 7}$ & $\mathrm{C}_{10} \mathrm{H}_{16}$ & $\mathrm{MH}$ \\
\hline 13.615 & Cyclopentene & 0.12 & $\mathrm{C}_{5} \mathrm{H}_{8}$ & $\mathrm{MH}$ \\
\hline 13.671 & $1,4-$-Cyclohexadiene & 0.39 & $\mathrm{C}_{10} \mathrm{H}_{16}$ & $\mathrm{MH}$ \\
\hline 14.722 & Cyclohexene & 0.15 & $\mathrm{C}_{6} \mathrm{H}_{10}$ & MH \\
\hline 15.333 & Linalool & 1.83 & $\mathrm{C}_{10} \mathrm{H}_{18} \mathrm{O}$ & $\mathrm{OM}$ \\
\hline 15.505 & Nonanal & 0.54 & $\mathrm{C}_{9} \mathrm{H}_{18} \mathrm{O}$ & AAI \\
\hline 16.462 & 2,6 -Dimethyl-1,3,5,7- & 0.89 & $\mathrm{C}_{10} \mathrm{H}_{16}$ & $\mathrm{MH}$ \\
& octatetraene & & & \\
\hline 16.873 & $2,4,6$-Octatriene & 1.18 & $\mathrm{C}_{10} \mathrm{H}_{16}$ & AH \\
\hline 17.690 & Acetic acid & 0.27 & $\mathrm{C}_{2} \mathrm{H}_{4} \mathrm{O}_{2}$ & $\mathrm{OC}$ \\
\hline
\end{tabular}

e-ISSN: 2148-2683

\begin{tabular}{|c|c|c|c|c|}
\hline 20.559 & Pulegone & 0.04 & $\mathrm{C}_{10} \mathrm{H}_{16} \mathrm{O}$ & $\mathrm{MH}$ \\
\hline 22.470 & Benzo-2,3-pyrrole & 0.39 & $\mathrm{C}_{8} \mathrm{H}_{6} \mathrm{~S}$ & $\mathrm{OC}$ \\
\hline 24.489 & $\alpha$-Cubebene & 0.40 & $\mathrm{C}_{15} \mathrm{H}_{24}$ & SH \\
\hline 25.472 & $\alpha$-Copaene & 1.63 & $\mathrm{C}_{15} \mathrm{H}_{24}$ & SH \\
\hline 25.946 & $\beta$-Elemene & 2.45 & $\mathrm{C}_{15} \mathrm{H}_{24}$ & SH \\
\hline 26.955 & Caryophyllene & 5.03 & $\mathrm{C}_{15} \mathrm{H}_{24}$ & $\mathrm{SH}$ \\
\hline 27.810 & Cadina-1(6) & 0.10 & $\mathrm{C}_{15} \mathrm{H}_{24}$ & SH \\
\hline 28.132 & $\alpha$-Humulene & 0.56 & $\mathrm{C}_{15} \mathrm{H}_{24}$ & $\mathrm{SH}$ \\
\hline 28.342 & $\begin{array}{l}\text { Epi- } \\
\text { bicyclosesquiphellandrene }\end{array}$ & 0.16 & $\mathrm{C}_{10} \mathrm{H}_{16}$ & $\overline{\mathrm{OC}}$ \\
\hline 28.972 & Germacrene-D & 2.78 & $\mathrm{C}_{15} \mathrm{H}_{24}$ & SH \\
\hline 29.220 & $\beta$-Selinene & 0.22 & $\mathrm{C}_{15} \mathrm{H}_{24}$ & $\mathrm{SH}$ \\
\hline 29.449 & Germacrene-B & 1.80 & $\mathrm{C}_{15} \mathrm{H}_{24}$ & $\mathrm{SH}$ \\
\hline 29.550 & $\alpha$-Muurolene & 0.19 & $\mathrm{C}_{15} \mathrm{H}_{24}$ & SH \\
\hline 29.718 & Farnesene & 0.12 & $\mathrm{C}_{15} \mathrm{H}_{24}$ & $\mathrm{SH}$ \\
\hline 30.004 & $\delta$-Cadinene & 0.74 & $\mathrm{C}_{15} \mathrm{H}_{24}$ & SH \\
\hline \multirow[t]{9}{*}{30.171} & $\Delta$-Cadinene & 1.16 & $\mathrm{C}_{15} \mathrm{H}_{24}$ & $\mathrm{SH}$ \\
\hline & & 99,04 & & \\
\hline & Component number & 33 & & \\
\hline & AH: Aromatic hydrocarbon & 1,18 & & \\
\hline & $\begin{array}{l}\text { MH: Monoterpene } \\
\text { hydrocarbon }\end{array}$ & 69,01 & & \\
\hline & OC: Other compounds & 0,82 & & \\
\hline & $\begin{array}{l}\text { SH: } \\
\text { hydrocarbon }\end{array}$ & 18,01 & & \\
\hline & $\begin{array}{ll}\text { OM: } & \text { Oxygenated } \\
\text { monoterpene } & \\
\end{array}$ & 9,48 & & \\
\hline & AAI: Aromatic aldehyde & 0,54 & & \\
\hline
\end{tabular}

In this study, the main volatile compounds in the essential oil of the $C$. praecox flower samples collected from parks and gardens in Burdur (Gölhisar) were determined respectively as $\beta$ Ocimene $(61.87 \%)$, Sabinene $(7.65 \%)$ and Caryophyllene $(5.03 \%)$. In the literature, the contents of floral aromatic compounds determined in Chimonanthus specimens from different geographical regions have shown significant variations. Floral fragrance compounds of $C$. praecox were determined mainly as terpenes, benzene-derivatives, alkanes, esters, and acids (Lin, 2019). Noticeable differences have been observed in $C$. praecox flower specimens with different colors collected from the same region. For example, the main aromatic compounds in $C$. nitens, $C$. zhejiangensis and $C$. salicifolius flowers collected from Zhejiang were determined as hedycaryol and $\alpha$-myrcene $(\mathrm{Xu}$, 2016). Furthermore, linalool, benzyl acetate, trans- $\beta$-ocimene and $\beta$-ocimene were found in different genotypes of $C$. praecox collected from Wuhan, and it was reported that the concentrations of these floral aromatic compounds were also different (Yu, 2013; $\mathrm{Li}, 2015)$. It was also observed that the floral aromatic compound contents of the same variety of $C$. praecox collected from different plantation areas showed differences. For instance, the main floral aromatic compounds of $C$. nitens collected from Zhejiang and Jiangxi were respectively hedycaryol and $\alpha$-myrcene (Xu et al., 2016) and dehydro-aromadendrene and (-)-spathulenol (Xu et al., 2006). In C. praecox var. concolor specimens, the main floral aromatic compounds from Hubei and Sichuan were reported respectively as alloocimene and benzyl acetate (Zhou et al., 2010) and z-muurolene and z-elemene (Li et al., 2008), benzyl acetate and alloocimene (Zhou et al., 2010) and elemol and z-elemene ( $\mathrm{Li}$ et al., 2008).

Different studies have determined the main aromatic compounds of $C$. praecox var. concolor flowers as trans- $\beta$ ocimene linalool and $\beta$-myrcene (Zhou et al., 2007), alloocimene, benzyl acetate and methyl salicylate (Zhou et al., 2010), linalool, benzyl acetate and methyl salicylate (Yu, 2013), linalool, benzyl alcohol and methyl salicylate (Li, 2015), and consecutively $\varepsilon$ muurolene, $\delta$-elemene and L-bornyl acetate (Li et al., 2008). The main floral aromatic compounds of $C$. praecox var. patens have 
been found as benzyl acetate, linalool and caryophyllene (Zhou et al., 2007), benzyl acetate, alloocimene and methyl salicylate (Zhou et al., 2010), linalool, benzyl acetate and methyl salicylate (Yu, 2013), $\beta$-ocimene, linalool and benzyl acetate (Li, 2015), elemol, z-elemene and $\beta$-Cubebene (Li et al., 2008). Considering previous studies, it may be seen that the compounds that we identified as the main volatile compounds in our study and their concentrations differed from those in other studies. As mentioned in the literature, different geographical regions and different flower colors have a significant effect on the aromatic compounds of $C$. praecox flowers. This study is expected to form a basis for the diversification and prevalence of the usage areas of $C$. praecox by determining the floral aromatic compounds of $C$. praecox growing in the Burdur (Gölhisar) region in Turkey, and cultivation studies are expected to accelerate.

\section{References}

Alves-Silva, J.M., Guerra, I., Gonçalves, M.J., Cavaleiro, C., Cruz, M.T., Figueirinha, A. \& Salgueiro, L. (2020). Chemical composition of Crithmum maritimum L. essential oil and hydrodistillation residual water by GC-MS and HPLC-DADMS/MS, and their biological activities. Ind. Crop Prod. 149, 112329.

Gao, Y., Jin, F.Y., \& Wang, X.P. (2011). The analysis of volatile oil for Chimonanthus praecox by GC-MS [J]. Lishizhen Med Mater Med Res, 22(3), 122-123.

Genç, L. (2010). Usage Areas and Ethics of Medicinal and Aromatic Plants, Anadolu University Publications, Eskişehir.329.

Giray F.H. (2018). An Analysis of World Lavender Oil Markets and Lessons for Turkey, Journal of Essential Oil Bearing Plants, 21(6), 1612-1623.

Güner, A., Aslan, S., Ekim, T., Vural, M., \& Babaç, M.T. (edlr.) (2012). List of plants of Turkey: (tracheophytes). Nezahat Gökyiğit Botanical Garden Press., İstanbul.

Kevseroğlu, K.. (1993). The place and importance of plants containing essential oil in medicine and other industries. OMÜ Journal of the Faculty of Agriculture, 8(1), 254-264.

Kitajima, M., Mori, I., Arai, K., Kogure, N., \& Takayama, H. (2006). Two new tryptamine-derived alkaloids from Chimonanthus praecox f. concolor. Tetrahedron Letters, 47(19), 3199-3202.

Lawless, J. (1995). The illustrated encyclopedia of essential oils: the complete illustrated guide to the use of oils in aromatherapy and herbalism. Shaftesbury, Dorset, UK: Element.

Li, Y.Y. (2015). Study of Floral Volatile Components and Lins Promoter Structure in Wintersweet. Master's Thesis, Huazhong Agricultural University, Wuhan, China

Li, Z. G., Liu, M. C., Deng, W., Wang, X. Y., Wang, G. M., \& Yang, Y. W. (2008). Comparative analysis of the essential oil from two Chimonanthus praecox cultivars. Fine Chemicals, 25(10), 985-988.

Lin, X. (2019). Research Pogresson Volatile Components of Chimonanthus Lindl. Fujian Agric. Sci. Technol., (7), 57-64.

Lv, J.F.; Zhang, L.L., Chu, X.Z., \& Zhou, J.F. (2012). Chemical composition, antioxidant and antimicrobial activity of the extracts of the flowers of the Chinese plant Chimonanthus praecox. Nat. Prod. Res.26(14), 1363-1367.

Ma, X.M., Wu, C.F., \& Peng, R.R. (2010).Advance in studies on Chimonanthus praecox [J]. J Anhui Agri Sci, , 38(34): 1927919280.
Maksimovic, Z.A., Dordevic, S. \& Mraovic, M. (2005). Antimicrobial activity of Chenopodium botrys essential oil. Fitoterapia.76,112-114.

Morikawa, T., Nakanishi, Y., Ninomiya, K., Matsuda, H., Nakashima, S., Miyashita, H., Yoshikawa, M., \& Hayakawa, T. (2014). Dimeric pyrrolidinoindoline-type alkaloids with melanogenesis inhibitory activity in flower buds of Chimonanthus praecox. J. Nat. Med., 68(3), 539-549.

Rota, M.C., Herrera A., Martinez, R.M., Sotomayor, J.A., \& Jordan M.J. (2008). Antimicrobial activity and chemical composition of Thymus vulgaris, Thymus zygis and Thymus hyemalis essential oils, Food Control, 19(7), 681-687.

Sahito, Z. A., Khan, D., Zehra, A., \& Zaki, M. J. (2019). Varıation In Pseudocarp- And Seed-Size And Seed Packaging Cost In Chımonanthus Praecox (L.) Link. (Family Calycanthaceae) From Chengdu, Sichuan Province, China Int. J. Biol. Blotech., 16 (3), 835-848.

Shu, R., Wan, Y., Wang, X. (2019). Non-volatile constituents and pharmacology of Chimonanthus: a review. Chin J Nat Med. 17(3), 161-186.

Siddique, S., Perveen, Z., Nawaz, S., Shahzad K. \& Ali, Z. (2015). Chemical composition and antimicrobial activities of essential oils of six species from family Myrtaceae. J. Essent. Oil Bear. Plants, 18(4), 950-956.

Söğüt, Z. (2018). Evaluation of using exotic plant species at Turkey. International Geography Symposium on the 30th Anniversary of TUCAUM. 3-6 Ekim 2018 /3-6 October 2018, Ankara.

Takayama, H., Matsuda, Y., Masubuchi, K., Ishida, A., Kitajima, M., \& Aimi, N. (2004). Isolation, structure elucidation, and total synthesis of two new Chimonanthus alkaloids, chimonamidine and chimonanthidine. Tetrahedron, 60(4). 893-900.

Ueyama, Y., Hashimoto, S., Nii, H., \& Furukawa, K. (1990). The volatile constituents of the flower concrete of Chimonanthus praecox Link. From China J. Flavour Fragr J., 5(2),85-88.

Wang, L.Y., Zhang, Z.B., Zhou, Z.R., \& Zhu, D. (2012). Advances in studies on chemical constitutions and pharmacological action of Chimonanthus praecox, Lishizhen Med Mater Med Res, 23(12), 3103-3106.

Wang, W., Cao, L., Xiong, J., Xia, G., \& Hu, J. (2011). Constituents from Chimonanthus praecox (wintersweet). Phytochem Lett. 4(3), 271-274.

Xu, M., Zhang, J.W., Wu, L.S., Liu, J.J., Si, J.P., \& Zhang, X.F. (2016). Determination of Volatile Components from Chimonanthus Flowers by HS-SPME-GC-MS. Sci. Silvae Sin., 52(12), 58-65.

Xu, N.J., Bai, H.B., Yan, X.J., \& Xu, J.L. (2006). Analysis of Volatile Components in Essential Oil of Chimonanthus nitens by Capillary Gas Chromatography-Mass Spectrometry. Instrum. Anal. 25(1), 90-93.

$\mathrm{Xu}$, W.Y., \& Jiang, P. (2000). Development and clinical application of Chimonanthus praecox flower cough syrup. Acta Acad. Med. Suzhou, 20(1), 122-123.

Yayl, N., (2013). Essential Oils and Their Medicinal Uses, Karadeniz Technical University, Faculty of Pharmacy Press, 1-2-4.

Yu, C-L., Kuang, Y.I, Yang S. X., LIU, L. \& Liu, C-G. (2013). Chemical Composition, Antifungal Activity and Toxicity of Essential Oils from Leaves of Chimonanthus praecox and Chimonanthus zhejiangensis. Asian Journal of Chemistry, 26(1), 254-256 
Zhang, J.W, Gao, J.M., Xu, T., Zhang, X.C, Ma, Y.T., Jarussophon, S., \&Konishi, Y. (2009). Antifungal activity of alkaloids from the seeds of Chimonanthus praecox [J]. Chem Biodivers, 6(6), 838-845.

Zhao, Y., Zhang, Y., \& Wang, Z.Z. (2010). Chemical composition and biological activities of essential oil from flower of Chimonanthus praecox (L.) link. Lishizhen Med Material Med Res.,21,622-5.

Zhou, J.R., \& Ni, D.J. (2010). Changes in Flower Aroma Compounds of Cultivars of Chimonanthus praecox (L.) Link and at Different Stages Relative to Chimonanthus Tea Quality. Acta Hortic. Sin.,37(10), 1621-1628.

Zhou, M.Q., Xiang, L., \& Chen, L.Q. (2007). Reliminary Studies on the Components of Volatile Floral Flavor and Flower Pigments of Chimonanthus praecox. Beijing For. Univ., 29, $22-25$. 